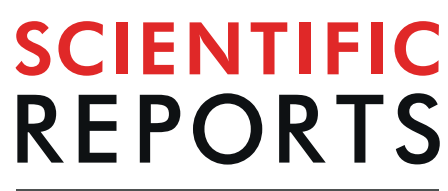

\title{
Drivers of Microbial Carbon Fluxes Variability in Two Oligotrophic Mediterranean Coastal Systems
}

\author{
Natalia González-Benítez $\mathbb{D}^{1,2,3^{*}}$, Lara S. García-Corral $\mathbb{D}^{3}$, Xosé Anxelu G. Morán $\mathbb{D}^{4}$, \\ Jack J. Middelburg $\oplus^{5,6}$, Marie Dominique Pizay ${ }^{1,2}$ \& Jean-Pierre Gattuso $\mathbb{D}^{1,2}$
}

The carbon fluxes between phytoplankton and heterotrophic bacterioplankton were studied in two coastal oligotrophic sites in the NW Mediterranean. Phytoplankton and bacterial production rates were measured under natural conditions using different methods. In the Bay of Villefranche, the temporal variability revealed net heterotrophy in July-October and net autotrophy in December-March. The spatial variability was studied in the Bay of Palma, showing net autotrophic areas in the west and heterotrophic areas in the east. On average bacterial respiration, represented $62 \%$ of the total community respiration. Bacterial growth efficiency (BGE) values were significantly higher in autotrophic conditions than in heterotrophic ones. During autotrophic periods, dissolved primary production (DPP) was enough to sustained bacterial metabolism, although it showed a positive correlation with organic carbon stock (DOC). Under heterotrophic conditions, DPP did not sustain bacterial metabolism but bacterial respiration correlated with DPP and bacterial production with DOC. Temperature affected positively, DOC, BGE, bacterial respiration and production when the trophic status was autotrophic. To summarize, the response of bacterial metabolism to temperature and carbon sources depends on the trophic status within these oligotrophic coastal systems.

Marine biogeochemical carbon fluxes are largely variable and their temporal and geographical distribution are essential to understand the oceanic carbon cycle. The database of gross primary production, community respiration and net community production ( $\mathrm{NCP}=$ gross primary production- community respiration) rates have increased considerably over the last years, but large gaps remain, especially for coastal oligotrophic areas ${ }^{1-3}$. In spite of their little area covering, approximately $7 \%$ of the surface of the global ocean, coastal waters account for $14 \%$ to $30 \%$ of total oceanic primary production ${ }^{4}$, which are highly variable in space and time and have a great ecological and social interest ${ }^{5}$. The metabolic balance or NCP informs us whether a marine ecosystem is net autotrophic (i.e. gross primary production $>$ community respiration) or net heterotrophic (i.e. gross primary production $<$ community respiration $)^{6,7}$. Available data of oceanic primary production is mostly obtained from productive areas. However, there are orders of magnitude fewer measurements addressing in coastal oligotrophic regions, the carbon fluxes links between bacterial metabolism and the partitioning among dissolved (DPP) and particulate (PPP) primary production. Understanding how bacteria influence the cycling of organic carbon it is key to assess their role in the ecosystem metabolic balance ${ }^{8}$.

In oligotrophic Mediterranean coastal waters, it has been shown that large supply of dissolved organic carbon (DOC) from land can sustain elevated community respiration, resulting in net heterotrophy ${ }^{9-11}$. Autochthonous DOC, either released from normal algal growth or resulting from trophic interactions ${ }^{12,13}$, represent a large fraction (from 20 to $80 \%$ ) of total primary production (DPP + PPP) in oligotrophic systems ${ }^{14-16}$. Indeed, the relative contribution of DPP to total primary production is considered an important autochthonous organic carbon source also for heterotrophic bacteria ${ }^{17}$, being considered by some authors as inverse ${ }^{18}$ or constant $^{19}$ to

\footnotetext{
${ }^{1}$ Sorbonne Université, CNRS, Laboratoire d'Océanographie de Villefranche, 181 chemin du Lazaret, F-06230, Villefranche-sur-mer, France. ${ }^{2}$ Institute for Sustainable Development and International Relations, Sciences Po, 27 rue Saint Guillaume, F-75007, Paris, France. ${ }^{3}$ Department of Biology, Geology, Physics and Inorganic Chemistry, King Juan Carlos University, C/Tulipán s/n, 28933, Móstoles, Madrid, Spain. ${ }^{4}$ King Abdullah University of Science and Technology (KAUST), Red Sea Research Center, Biological and Environmental Sciences and Engineering Division, 23955-6900, Thuwal, Saudi Arabia. ${ }^{5}$ Department of Estuarine and Delta Systems, NIOZ Royal Netherlands Institute for Sea Research and Utrecht University, Yerseke, The Netherlands. ${ }^{6}$ Department of Earth Sciences, Utrecht University, Princetonlaan 8A, 3584 CB, Utrecht, The Netherlands. *email: natalia.gonzalez@urjc.es
} 


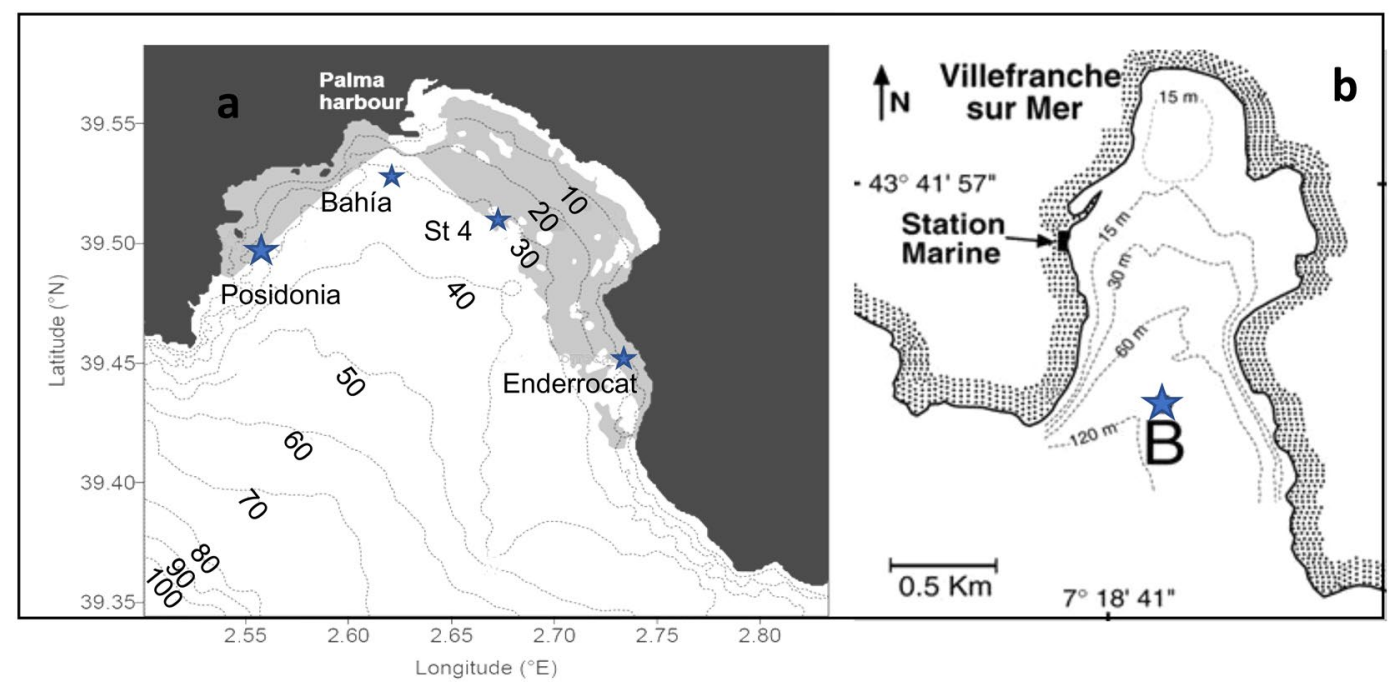

Figure 1. Study sites in (a) the Bay of Palma and (b) the Bay of Villefranche sur Mer. Stars show the location of the sampled stations.

the productivity of the system. Bacterial carbon demand includes all the organic carbon assimilated by heterotrophic bacteria, which can be allocated into anabolic (bacterial production) and catabolic processes (bacterial respiration).

Currently, there is some debate about the dependence of bacterial carbon demand on phytoplankton production, mainly within oligotrophic systems ${ }^{20,21}$. In offshore areas not influenced by carbon inputs from land, phytoplankton primary production was reported to sustain bacterial carbon demand ${ }^{18}$, but the generality of this observation for inshore regions has not yet been confirmed ${ }^{22}$. Other authors ${ }^{21}$ suggested that bacterial carbon demand always exceeds contemporaneous primary production in all aquatic systems. Bacterial carbon demand is governed by bacterial growth efficiency (BGE = bacterial production/bacterial carbon demand), however there is a large range of variation in $\mathrm{BGE}\left(5-60 \%{ }^{23}\right.$;). In many instances, $\mathrm{BGE}$ is not directly measured but inferred from literature models ${ }^{24,25}$, which are generally biased with data from productive areas. Therefore, there is a lack of data about the BGE regulation in oligotrophic coastal waters ${ }^{14,24,26-28}$.

Ideally, direct measurements of net microbial carbon production and consumption should be used ${ }^{29}$ but bacterial production is usually measured in unfiltered samples and with short incubation times whereas bacterial respiration is measured in filtered samples with longer incubation times. In many studies bacterial respiration is derived from biomass and production data ${ }^{30-32}$. Moreover, disentangling the factors that control the carbon fluxes dynamics of marine microbial communities is challenging. The temperature dependence of biological processes has been traditionally expressed using the Van't Hoff-Arrhenius equation also known as Boltzmann's factor ${ }^{33-35}$. According to this expression, the slope of the natural logarithm of a metabolic rate against the temperature function $1 / \mathrm{kT}$, where $\mathrm{k}$ is Boltzmann's constant and $\mathrm{T}$ is the absolute temperature (Kelvin degrees), represents the activation energy (Ea) of that particular metabolic process ${ }^{33-35}$. Temperature has been described to play a major role regulating the metabolism of Mediterranean plankton communities ${ }^{36,37}$. Here we test how the metabolic status or balance of the plankton community can affect the temperature-dependence of microbial metabolism in these ecosystems.

To improve our knowledge of the trophic status in oligotrophic bays, it is necessary to focus the studies on temporal and spatial variability, despite the given idea that these environments as steady state systems. To reach this goal, we performed simultaneous measurements of net community production, particulate and dissolved primary production, bacterial production and respiration, thus allowing direct BGE, bacterial carbon demand and conversion factor values. The study was carried out in two oligotrophic coastal ecosystems in the NW Mediterranean (Fig. 1). The temporal variability was studied within the Bay of Villefranche (France) and the spatial variability was focused in July within the Bay of Palma (Spain), during the period most limited by nutrients. The comparison and join, of both bays is based on the environmental similarities of these regions ${ }^{2,10}$. The results will improve further understanding of the link between carbon fluxes and the metabolic trophic status, of these marine coastal ecosystems.

\section{Results}

Effect of filtration and incubation time on bacterial metabolism estimations. To estimate the effect of filtration on bacterial metabolism, bacterial production, bacterial abundance and DOC concentration were compared between filtered and unfiltered samples. DOC concentration in unfiltered $\left(83 \pm 3 \mu \mathrm{mol}^{-1}\right)$ and filtered $\left(97 \pm 5 \mu \mathrm{mol} \mathrm{l}^{-1}\right)$ samples were significantly different (paired t-test; $\mathrm{t}_{21}=3, \mathrm{p}<0.01, \mathrm{n}=22$ ). Bacterial abundance was not significantly different before $\left(6.92 \pm 0.48 \times 10^{5} \mathrm{cell} \mathrm{ml}^{-1}\right)$ and after filtration $\left(6.24 \pm 1.02 \times 10^{5}\right.$ cell $\left.\mathrm{ml}^{-1}\right)$. Bacterial production was significantly lower in filtered $(17.59 \pm 4.03)$ than in unfiltered $(66.45 \pm 11.41)$ samples (paired t-test; $\mathrm{t}_{83}=4.5, \mathrm{p}<0.001, \mathrm{n}=84$ ). Bacterial production was estimated after different periods of in situ incubation times (no incubation, 6 and $12 \mathrm{~h}$ ). After $12 \mathrm{~h}$ incubation bacterial production showed values 


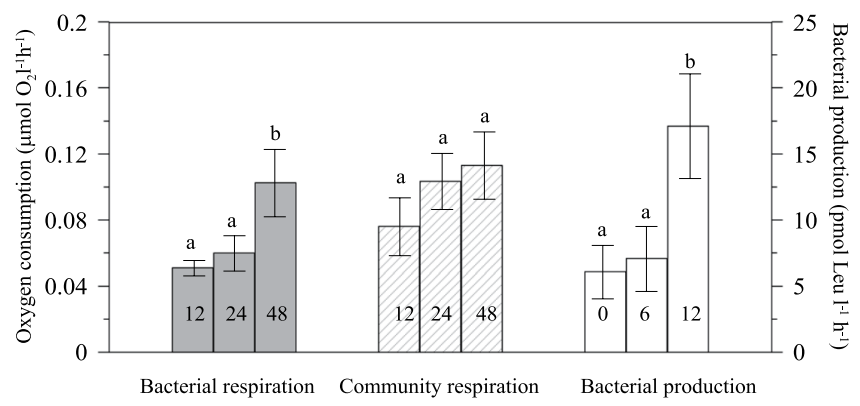

Figure 2. Effect of the incubation time under in situ simulated conditions on the respiration rates in filtered (bacterial respiration, BR) and unfiltered samples (community respiration, $\mathrm{CR}$ ) and bacterial production rates (BP). Error bars represent standard error $(n=16)$. Lower case letters denote significantly different mean values (ANOVA, $\mathrm{p}<0.05$; Student-Newman-Keul post-hoc). Numbers within the bars indicate the time of incubation in hours.

2.6-times higher compared with those incubated during shorter incubations $(0$ and $6 \mathrm{~h})\left(\mathrm{F}_{2,45}=4.3, \mathrm{n}=48\right.$, $\mathrm{p}=0.02$; Fig. 2). Also, a significant effect of incubation time was observed in bacterial respiration rates (Fig. 2; $\mathrm{F}_{2,21}=4.1, \mathrm{n}=24, \mathrm{p}=0.03$ ), with higher values after $48 \mathrm{~h}$ than after 12 and $24 \mathrm{~h}$ (Fig. 2). However, the duration of incubation had no significant effect on unfiltered samples. BGE and bacterial carbon demand are usually estimated using bacterial production and respiration rates which are commonly incubated during different time lengths. In order to minimize possible bias, $\mathrm{BGE}_{12}$ and $\mathrm{BCD}_{12}$ in our experiments were estimated using bacterial respiration and production measurements from pre-filtered samples both incubated during 12 hours (see material and methods). The average percentage of oxygen consumption in filtered seawater samples (12 and $24 \mathrm{~h}$ ) compared to whole seawater samples, were enabled to estimate bacterial respiration.

Temporal variability in the Bay of Villefranche. As expected, irradiance showed a seasonal pattern with the highest values found during July followed by October, December and March (Table 1). The lowest temperatures were recorded in March $\left(13.2^{\circ} \mathrm{C}\right.$ throughout the water column) and the highest in July, coincident with the strongest stratification (Table 1). Changes in the percentage of $\mathrm{O}_{2}$ saturation were similar to those of temperature, with oxygen-saturated waters during July and below $100 \%$ during the rest of the year (Table 1, Fig. 3). The concentrations of $\mathrm{NO}^{-}{ }_{3}$ and $\mathrm{Si}(\mathrm{OH})_{4}$ were lower than $1 \mu \mathrm{mol} \mathrm{l}^{-1}$ except in March (Table 1). The highest DOC concentrations were during July $\left(70.7 \pm 2.2 \mu \mathrm{mol}^{-1}\right)$ and the lowest during March $\left(63.8 \pm 0.6 \mu \mathrm{mol} 1^{-1}\right.$; Table 1$)$.

Chlorophyll- $a$ concentrations varied considerably (from 0.1 to $1.1 \mathrm{mg} \mathrm{m}^{-3}$ ) across depths and months, with mean values increasing from summer to spring (Fig. 3). The picophytoplankton community composition was dominated by Synechococcus cyanobacteria. The highest abundances of Synechococcus were found in October and July, while Prochlorococcus peaked in December and October and photosynthetic picoeukaryotes in March. Heterotrophic prokaryotes abundances ranged from 6.1 to $12.3 \times 10^{5}$ cells $\mathrm{ml}^{-1}$, with the highest abundances measured in December and the lowest in October (Fig. 3). Picoautotrophs biomass average contributed with 9.4 $( \pm 1.1) \%$ of the total autotrophic biomass (Chl- $a)$.

Primary production was generally low, with DPP and PPP ranging from 0.02 to $1.36 \mathrm{mg} \mathrm{C} \mathrm{m}^{-3} \mathrm{~h}^{-1}$ and 0.03 to $2.10 \mathrm{mg} \mathrm{C} \mathrm{m}^{-3} \mathrm{~h}^{-1}$; respectively, with the highest values observed in the spring bloom period during March (Fig. 4). Percentage of extracellular release was highly variable, from 5.0 to $86.6 \%$, with the lowest values recorded in December and the highest ones in October (Table 1, Fig. 4). Heterotrophic bacterial production showed a minimum of $1.6 \pm 0.4 \mathrm{pmol} \mathrm{Leu}^{-1} \mathrm{~h}^{-1}$ in March (equivalent to $0.002 \mathrm{mg} \mathrm{C} \mathrm{m}^{-3} \mathrm{~h}^{-1}$ ) and a maximum of $14.9 \pm 6.6$ pmol Leu $\mathrm{l}^{-1} \mathrm{~h}^{-1}$ in July $\left(0.02 \mathrm{mg} \mathrm{C} \mathrm{m}^{-3} \mathrm{~h}^{-1}\right)$. Indeed, bacterial respiration (BR) was lowest in December $\left(0.01 \pm 0.004 \mu \mathrm{mol} \mathrm{O}_{2} \mathrm{l}^{-1} \mathrm{~h}^{-1}\right)$ and highest in October $\left(0.04 \pm 0.01 \mu \mathrm{mol} \mathrm{O} \mathrm{l}^{-1} \mathrm{~h}^{-1}\right)$ (Fig. 4). BGE 12 ranged from 0.3 to $22.4 \%$, with the highest value in summer and lowest in spring (Table 1 ).

Spatial variability in the Bay of Palma. Irradiance and temperature values were very similar between stations, with approximately $500 \mu \mathrm{mol}$ photons $\mathrm{m}^{-2} \mathrm{~s}^{-1}$ and $22.2^{\circ} \mathrm{C}$ (Table 1). Salinity averaged 37.8 psu and mean $\mathrm{O}_{2}$ saturation were above $100 \%$ saturation across sites (Table 1, Fig. 3). Low dissolved inorganic nutrient concentrations characterized these oligotrophic waters, with $\mathrm{NO}^{-}{ }_{3}$ and $\mathrm{Si}(\mathrm{OH})_{4}$ always below or equal to $1 \mu \mathrm{mol} \mathrm{l}^{-1}$ (Table 1). DOC concentration was higher at the western stations Posidonia and Bahia, $(89.1 \pm 4.4$ and $85.5 \pm 1.7$; $\mu \mathrm{mol}^{-1}$, respectively (Fig. 1, Table 1). Chorophyll- $a$ values were below $0.5 \mathrm{mg} \mathrm{m}^{-3}$ and followed the same pattern as DOC with the highest values measured at Posidonia and Bahia stations (Fig. 3). Picophytoplankton community composition was dominated by Synechococcus spp across stations, with highest abundances measured at Bahia station (Fig. 3). Prochlorococcus spp peaked at Station 4 and photosynthetic picoeukaryotes at Bahia station. Heterotrophic prokaryotes abundance ranged from 2.4 to $9.4 \times 10^{5}$ cells ml $^{-1}$, with the highest abundances at Bahia and lowest at Station 4 station (Fig. 3). The average picoautotrophs biomass accounted 5.7\% $( \pm 0.7)$ of the total autotrophic biomass. Total primary production ranged from 0.16 to $2.99 \mathrm{mg} \mathrm{C} \mathrm{m}^{-3} \mathrm{~h}^{-1}$, with DPP ranging from 0.11 to $1.36 \mathrm{mg} \mathrm{C} \mathrm{m}^{-3} \mathrm{~h}^{-1}$ and PPP from 0.03 to $1.63 \mathrm{mg} \mathrm{C} \mathrm{m}^{-3} \mathrm{~h}^{-1}$. Highest values of both fractions, DPP and PPP, were measured at Posidonia station and the lowest at Enderrocat (Fig. 4). Percentage of extracellular release averaged $53.4 \pm 3.7 \%$, with highest values observed at Enderrocat station and similarly low values at Posidonia and Bahia stations showing an opposite tendency of chlorophyll- $a$ and DOC (Table 1, Fig. 4). 


\begin{tabular}{|c|c|c|c|c|c|c|c|c|c|c|}
\hline & $\begin{array}{l}\text { Sampling } \\
\text { depths }\end{array}$ & Salinity & $\mathrm{O}_{2}$ Saturation & Irradiance & Temperature & $\mathrm{Si}(\mathrm{OH})_{4}$ & $\mathrm{NO}^{-}{ }_{3}$ & DOC & $\mathrm{BGE}_{12}$ & PER \\
\hline & $\mathbf{m}$ & psu & $\%$ & $\begin{array}{l}\mu \text { mol photons } \\
\mathrm{m}^{-2} \mathrm{~s}^{-1}\end{array}$ & ${ }^{\circ} \mathrm{C}$ & $\mu \mathrm{mol} 1^{-1}$ & $\mu \mathrm{mol} \mathrm{1} \mathbf{1}^{-1}$ & $\mu \mathrm{mol} \mathrm{1} \mathbf{1}^{-1}$ & $\%$ & $\%$ \\
\hline \multicolumn{11}{|c|}{ Bay of Villefranche } \\
\hline October & $0.5,10,20,30$ & 37.8 & $96.8 \pm 2.3$ & $462.5 \pm 277.8$ & $20.7 \pm 0.9$ & $0.1 \pm 0.0$ & $0.9 \pm 0.4$ & $66.3 \pm 1.0$ & $0.6 \pm 0.1$ & $55.8 \pm 7.2$ \\
\hline December & $0.5,10,20,30$ & 37.7 & $89.8 \pm 0.2$ & $261.7 \pm 164.6$ & $17.2 \pm 0.0$ & $0.8 \pm 0.0$ & $0.7 \pm 0.2$ & $64.4 \pm 1.6$ & $1.9 \pm 0.7$ & $20.4 \pm 6.7$ \\
\hline March & $0.5,10,20,30$ & 38.1 & $90.7 \pm 0.2$ & $184.2 \pm 72.2$ & $13.2 \pm 0.0$ & $1.7 \pm 0.4$ & $3.0 \pm 0.3$ & $63.8 \pm 0.6$ & $0.5 \pm 0.1$ & $54.8 \pm 12.8$ \\
\hline July & $0.5,10,20,30$ & 38.0 & $100.9 \pm 1.7$ & $675.0 \pm 318.1$ & $21.3 \pm 2.2$ & $0.7 \pm 0.1$ & $0.7 \pm 0.2$ & $70.7 \pm 2.2$ & $7.3 \pm 5.1$ & $31.6 \pm 7.2$ \\
\hline \multicolumn{11}{|c|}{ Bay of Palma } \\
\hline Posidonia & $0.5,3,6,10$ & 37.8 & $116.1 \pm 0.4$ & $581.7 \pm 166.5$ & $22.6 \pm 0.1$ & $0.4 \pm 0.1$ & $0.3 \pm 0.0$ & $89.1 \pm 4.4$ & $17.5 \pm 8.1$ & $36.5 \pm 7.1$ \\
\hline Bahia & $0.5,5,15,30$ & 37.8 & $110.1 \pm 0.7$ & $495.9 \pm 200.1$ & $22.4 \pm 0.7$ & $0.9 \pm 0.1$ & $0.3 \pm 0.0$ & $85.5 \pm 1.7$ & $10.9 \pm 3.3$ & $36.6 \pm 1.9$ \\
\hline Station 4 & $0.5,5,15,30$ & 37.8 & $107.6 \pm 0.2$ & $478.4 \pm 187.0$ & $20.8 \pm 0.7$ & $1.0 \pm 0.1$ & $0.4 \pm 0.0$ & $71.6 \pm 2.5$ & $3.4 \pm 1.1$ & $61.2 \pm 2.5$ \\
\hline Enderrocat & $0.5,5,10,15$ & 37.8 & $110.8 \pm 0.7$ & $619.2 \pm 170.5$ & $23.0 \pm 0.5$ & $1.0 \pm 0.0$ & $0.3 \pm 0.0$ & $68.8 \pm 4.2$ & $1.1 \pm 0.5$ & $78.3 \pm 3.2$ \\
\hline
\end{tabular}

Table 1. Average $\pm S E$ values within the photic zone for selected variables at the different periods and stations sampled. Salinity, percentage of oxygen saturation, irradiance, temperature, silicate $\left(\mathrm{Si}(\mathrm{OH})_{4}\right)$, nitrate $\left(\mathrm{NO}^{-}{ }_{3}\right)$, dissolved organic carbon (DOC), bacterial growth efficiency $\left(\mathrm{BGE}_{12}\right)$ and percent extracellular release (PER).
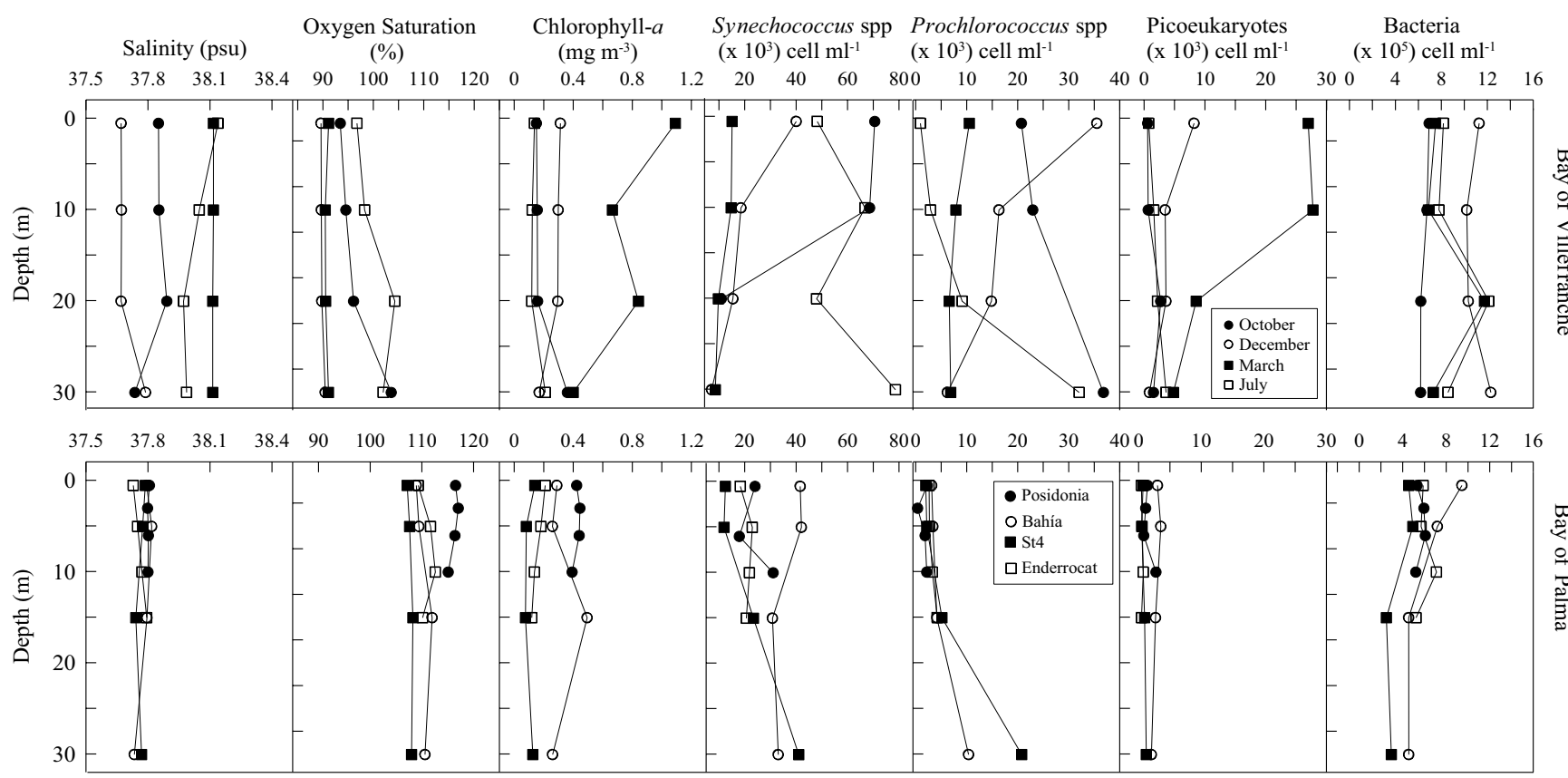

Figure 3. Vertical profiles of salinity (psu; practical salinity units), percentage of oxygen saturation,

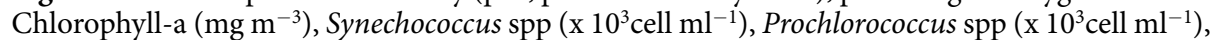
Picoeukaryotes $\left(\mathrm{x} 10^{3}\right.$ cell $\left.\mathrm{ml}^{-1}\right)$ and heterotrophic prokaryotes $\left(\mathrm{x} 10^{5} \mathrm{cell} \mathrm{m} \mathrm{m}^{-1}\right)$ abundances in the Bay of Villefranche (upper panels) and Bay of Palma (lower panels). Error bars represent standard error.

In the Bay of Palma, the lowest bacterial production was $11.8 \mathrm{pmol} \mathrm{Leu}^{-1} \mathrm{~h}^{-1}\left(0.01 \mathrm{mg} \mathrm{C} \mathrm{m}^{-3} \mathrm{~h}^{-1}\right)$ observed at Enderrocat station and the highest in Posidonia station of $252.9 \mathrm{pmol} \mathrm{Leu}^{-1} \mathrm{~h}^{-1}\left(0.29 \mathrm{mg} \mathrm{C} \mathrm{m}^{-3} \mathrm{~h}^{-1}\right)$ (Fig. 4). Bacterial respiration showed the lowest value at Bahia station, with $0.06 \mu \mathrm{mol} \mathrm{O} \mathrm{I}^{-1} \mathrm{~h}^{-1}$ and the highest at Station 4 station with $0.24 \mu \mathrm{mol} \mathrm{O}_{2} \mathrm{l}^{-1} \mathrm{~h}^{-1}$ (Fig. 4). $\mathrm{BGE}_{12}$ ranged from 0.3 to $40.6 \%$, with the highest mean values at Posidonia station and the lowest observed at the Enderrocat station (Table 1).

Effects of environmental and biological variables on bacterial metabolism on both bays. The temporal variability in the Bay of Villefranche included net heterotrophy during summer and autumn $(-0.2 \pm 0.2$ and $-0.4 \pm 0.1 \mu \mathrm{mol} \mathrm{O} \mathrm{O}^{-1} \mathrm{~d}^{-1}$, respectively) and net autotrophy during winter and spring $(0.6 \pm 0.4$ and $2.7 \pm 0.9$ $\mu \mathrm{mol} \mathrm{O} \mathrm{I}^{-1} \mathrm{~d}^{-1}$, respectively). The spatial variability in the Bay of Palma communities showed autotrophy at the western stations Posidonia and Bahia $\left(1.5 \pm 1.0\right.$ and $0.5 \pm 0.3 \mu \mathrm{mol} \mathrm{O}_{2} \mathrm{l}^{-1} \mathrm{~d}^{-1}$, respectively) and heterotrophy, in the eastern stations Enderrocat and Station $4\left(-1.8 \pm 1.5\right.$ and $-2.5 \pm 1.5 \mu \mathrm{mol} \mathrm{O} \mathrm{l}^{-1} \mathrm{~d}^{-1}$, respectively).

All data were grouped into two categories regardless of the location and from an ecophysiological point of view: net autotrophic $(\mathrm{NCP}>0)$ and net heterotrophic $(\mathrm{NCP}<0)$. Coherently, results confirmed that DPP and 


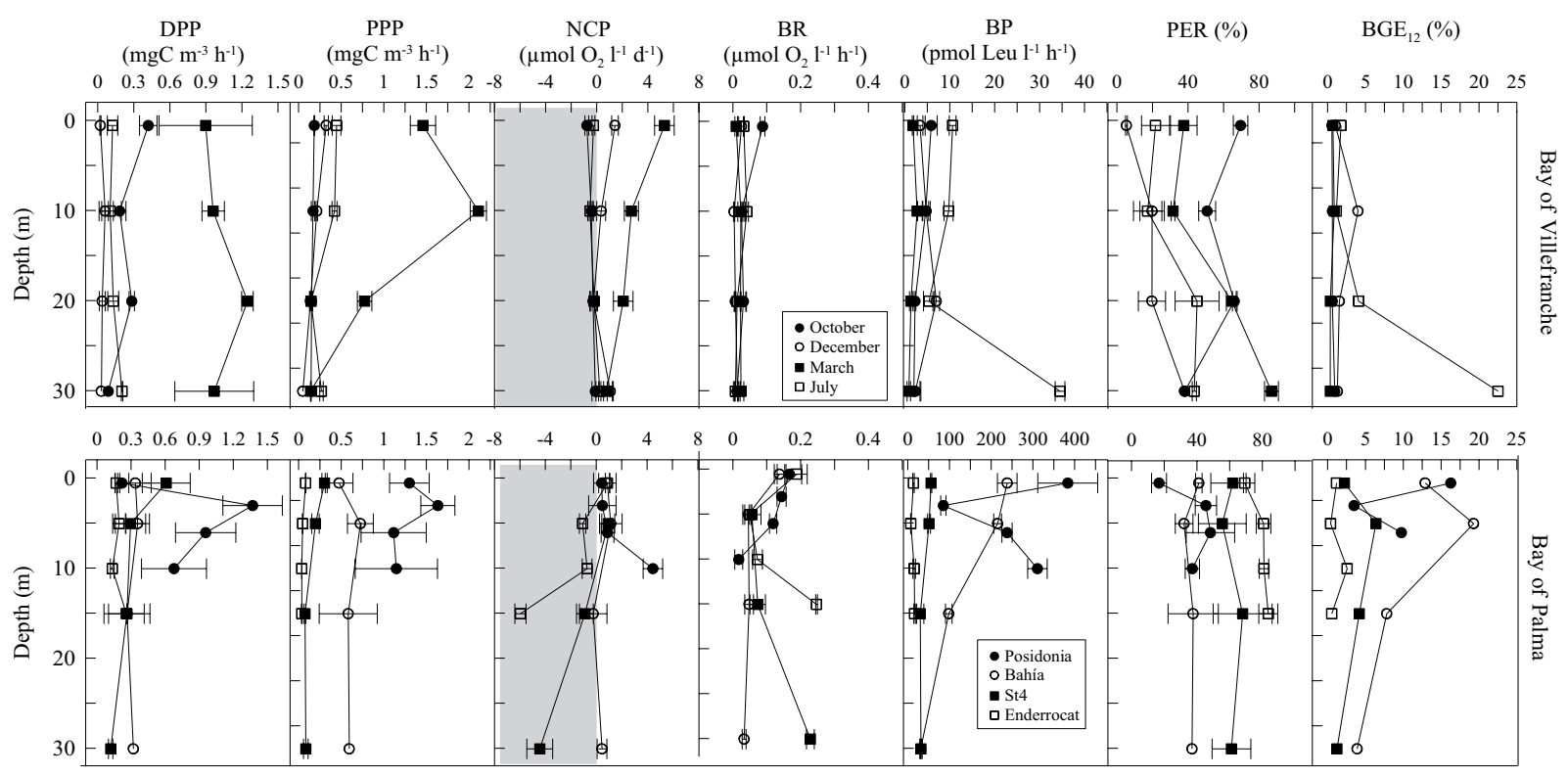

Figure 4. Vertical profiles of the rates of dissolved (DPP) and particulate (PPP) primary production (mg $\mathrm{C} \mathrm{m}^{-3} \mathrm{~h}^{-1}$ ), net community production (NCP, $\mu$ mol O $\left.\mathrm{O}_{2} \mathrm{l}^{-1} \mathrm{~d}^{-1}\right)$, bacterial respiration $\left(\mathrm{BR}, \mu \mathrm{mol} \mathrm{O} \mathrm{l}^{-1} \mathrm{~h}^{-1}\right.$ ) and bacterial production (BP, pmol Leu $\left.\mathrm{l}^{-1} \mathrm{~h}^{-1}\right)$. Also show the percent extracellular release (PER $=\mathrm{DPP} /$ $[\mathrm{DPP}+\mathrm{PPP}])$ and bacterial growth efficiency $\left(\mathrm{BGE}_{12}, \%\right)$ in the Bay of Villefranche (upper panels) and the Bay of Palma (lower panels). Error bars represent standard error.

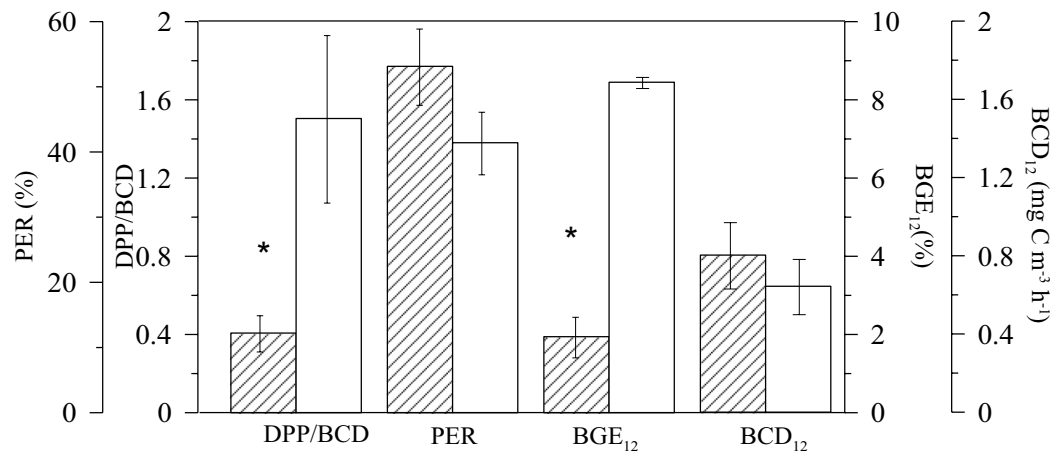

Figure 5. Effect of the trophic state (empty bars are autotrophic and dashed bars are heterotrophic) on Dissolved Primary Production /Bacterial Carbon Demand ratio (DPP/BCD), Percentage of Extracellular Release (PER), Bacterial Growth Efficiency $\left(\mathrm{BGE}_{12}\right)$ and Bacterial Carbon Demand $\left(\mathrm{BCD}_{12}\right)$. Error bars represent standard error. Significant differences are shown with an asterisk.

PPP were significantly higher in autotrophic relative to heterotrophic conditions $\left(\mathrm{F}_{1,30}=7.1, \mathrm{n}=32, \mathrm{p}=0.01\right.$ and $\mathrm{F}_{1,30}=10.8, \mathrm{n}=32, \mathrm{p}=0.002$, respectively). DPP sustained bacterial carbon demand under autotrophic conditions $(\mathrm{DPP} / \mathrm{BCD}=1.5 \pm 0.4)$, whereas it did not under heterotrophic (DPP/BCD $=0.4 \pm 0.1$; Fig. 5). BGE was also significantly higher $\left(\mathrm{F}_{1,30}=5.1, \mathrm{n}=32, \mathrm{p}=0.03\right)$ in autotrophic than in heterotrophic communities $(8.5 \pm 2.6 \%$ vs $1.9 \pm 0.5 \%)$ (Fig. 5$)$. However, percentage of extracellular release and bacterial carbon demand showed no significant differences between trophic status; respectively $\left(\mathrm{F}_{1,30}=1.7, \mathrm{n}=32, \mathrm{p}>0.05\right.$ and $\mathrm{F}_{1,30}=0.5$, $\mathrm{n}=32, \mathrm{p}>0.05)$ (Fig. 5).

When differentiated according to NCP values, DPP and Chl- $a$ were positive and significant linearly correlated only within autotrophic communities $\left(\mathrm{R}^{2}=0.28, \mathrm{n}=17, \mathrm{p}=0.03\right)$, but not within heterotrophic ones $(\mathrm{p}>0.05$; Fig. 6a). Similarly, the linear regression between PPP and chlorophyll- $a$ was significant and positive for autotrophic communities $\left(\mathrm{R}^{2}=0.45, \mathrm{n}=17, \mathrm{p}=0.003\right)$, whereas no correlation was found in the heterotrophic ones ( $\mathrm{p}>0.05$; Fig. 6b).

Bacterial production showed a significant relationship with DOC concentration independently of the trophic status of the community (Fig. 7a) while bacterial respiration and carbon demand were correlated with DOC concentration only with autotrophic communities (Fig. 7b,c). In contrast, bacterial respiration was only significantly related to DPP in heterotrophic communities (Fig. 7e), whereas no relationships of bacterial production and carbon demand were observed with DPP (Fig. 7d,f). 

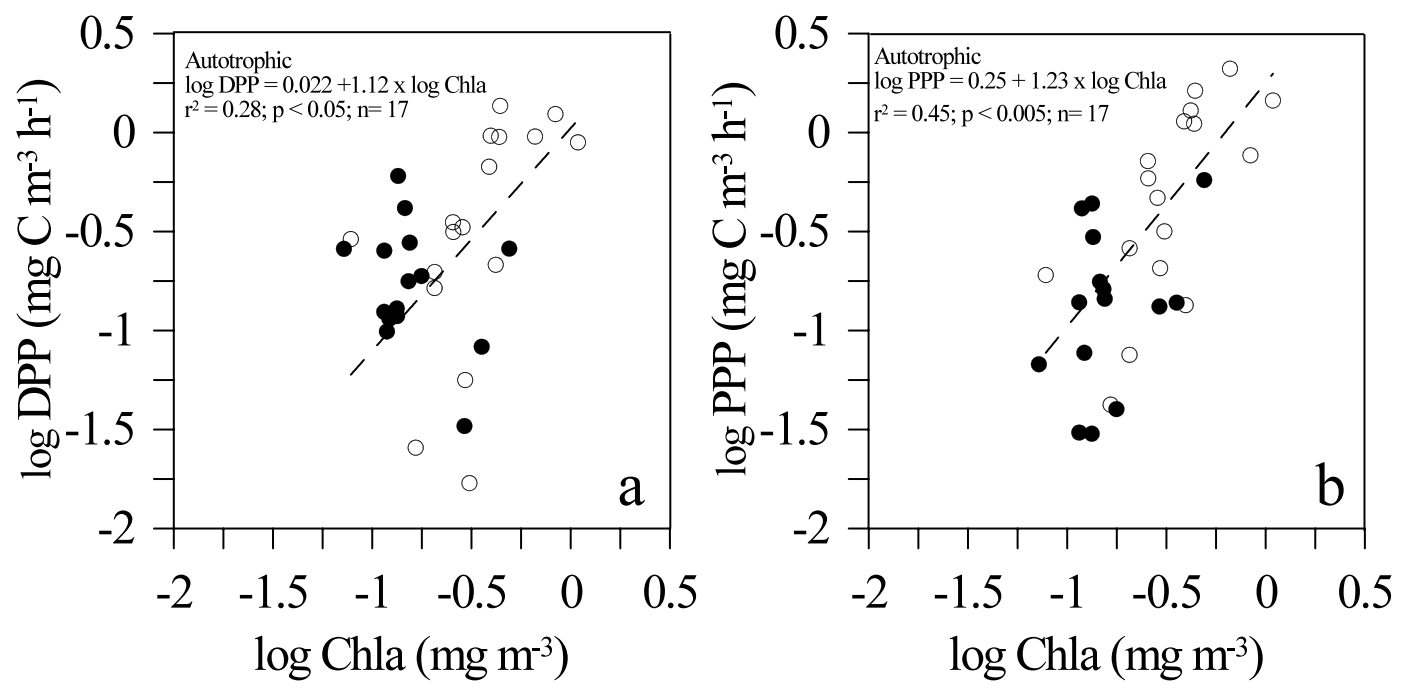

Figure 6. Relationship between Dissolved Primary Production (DPP) (a) and Particulate Primary Production (PPP) (b) with Chlorophyll- $a$ concentrations under autotrophic (white dots) and heterotrophic (black dots) conditions. Dashed lines represent the fitted Model II linear regressions for the significant relationship within autotrophic samples.

Bacterial production and respiration, BGE and DOC concentrations were positively correlated with temperature only under autotrophic conditions, but not under heterotrophic (Fig. 8a-d). The slope or activation energy of the Arrhenius relationship for bacterial production was $1.42 \mathrm{eV}, 0.67 \mathrm{eV}$ for bacterial respiration and $0.83 \mathrm{eV}$ for BGE.

\section{Discussion}

Relying on actual system-specific measurements rather than on literature or models results, does not completely solve the coupling degree between phytoplankton and heterotrophic bacterioplankton because measuring the flow of carbon through bacteria is methodologically challenging. For instance, bacterial respiration and production estimates may still bring uncertainties due to factors such as the incubation time, bottle effects, bottle opaque to UVB radiation, filtration artefacts or the choice substrate-to-carbon conversion factors ${ }^{29,37-39}$.

Our first concern was to make sure that bacterial abundance was not significantly different after filtration, so that metabolic processes measured in the filtered samples represented realistically the rates of bacterial respiration in the no processed samples.

Filtering process by the $0.8 \mu \mathrm{m}$ filters increases DOC concentration because some planktonic cells could have been broken, leaking part of their cytoplasmic content into the filtrate ${ }^{40}$. However, this process even if did not affect small bacteria it certainly had influence on attached bacteria ${ }^{29,41}$ which are not detected by the flow cytometer. For this reason, bacterial production was higher before the filtering process and heterotrophic prokaryotes abundance did not show any significant difference.

Since bottle effects are to some extent unavoidable (e.g. ${ }^{42}$ ), another factor contributing to uncertainty is the incubation time. Contrary to previous studies ${ }^{27}$, bacterial respiration and production did not show linear responses after 12 and $48 \mathrm{~h}$, respectively. This observation is not trivial, as most of the previous studies did not consider as a key variable the incubation time or the bottle effect ${ }^{14,36,43}$. Bacterial production is typically measured in unfiltered samples and incubated for a short period (2-8hours), whereas bacterial respiration is determined in filtered samples that are subsequently incubated for at least 24 or $48 \mathrm{~h}$. Bacterial respiration could be stimulated during long incubations $\left(48 \mathrm{~h}^{42}\right)$ by viral activity ${ }^{44}$ or by changes in bacterial community composition ${ }^{26,45}$. Shorter incubations (i.e. $<6 \mathrm{~h}$ ) limit the bottle effect and provide the most accurate consumption rates of labile $\mathrm{DOC}^{9}$. On the contrary, samples incubated for longer times will be exposed to higher cumulative processes, such as cell lysis, increasing DOC release and consequently increased bacterial production and respiration ${ }^{46}$.

Despite the methodological challenge, in this study we were able to demonstrate coherent patterns in bacterial carbon fluxes in two NW Mediterranean embayment's. Our direct rather than indirect estimations and the simultaneous temporal and spatial studies, might provide a new insight of the bacterial carbon fluxes and their temperature and metabolic status dependence within oligotrophic systems.

In this study, we measured an expected significantly higher chlorophyll-a concentrations under autotrophic periods (stations which values of NCP are higher than 0) compare to those concentrations under heterotrophic conditions $(\mathrm{NCP}<0)$. However, picophytoplankton biomass of the diverse groups measured, was not significantly different during heterotrophic and autotrophic periods. Indeed, regardless to the locations TPP, and consequently DPP and PPP, was significantly higher under autotrophic conditions compare to heterotrophic conditions. Contrary to previous works ${ }^{16,18}$ and in agreement with others ${ }^{19}$ differences in percentage of extracellular release average values between trophic states were not significant $(41 \pm 5 \%$ and $53 \pm 5 \%$ in autotrophic and heterotrophic systems, respectively). 

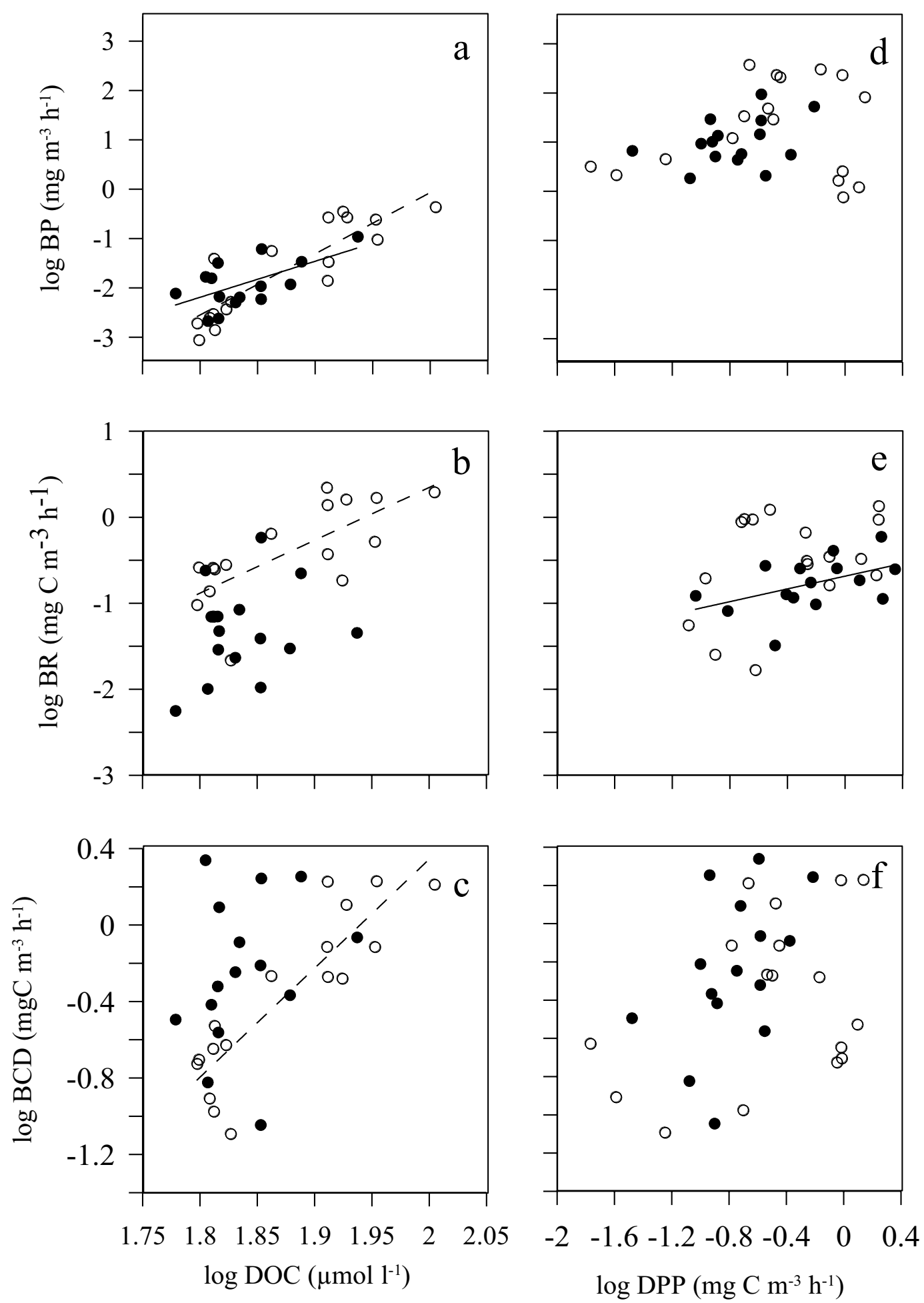

Figure 7. Relationship between: Dissolved Organic Carbon (DOC) and Dissolved Primary Production (DPP) with: Bacterial Production (BP) (a,d); Bacterial Respiration (BR) (b,e) and Bacterial Carbon Demand (BCD) $(\mathbf{c}, \mathbf{f})$. Black and white dots represent heterotrophic and autotrophic conditions, respectively. The solid line (for heterotrophic conditions) and dashed line (for autrotrophic conditions), represent the significant fitted Model II linear regressions. The equations parameters are: a) $\log \mathrm{BP}=-24.87+12.40 \times \log \mathrm{DOC} ; \mathrm{r}^{2}=0.76 ; \mathrm{p}<0.0001$; $\mathrm{n}=17$ (dashed line for autotrophic conditions). $\log \mathrm{BP}=-15.34+7.30 \times \log \mathrm{DOC} ; \mathrm{r}^{2}=0.36 ; \mathrm{p}<0.05 ; \mathrm{n}=15$ (solid line for heterotrophic conditions). (b) $\log \mathrm{BR}=-11.94+6.14 \times \log \mathrm{DOC} ; \mathrm{r}^{2}=0.53 ; \mathrm{p}=0.001, \mathrm{n}=17$ (dashed line for autotrophic conditions). (c) $\log \mathrm{BCD}=-11.07+5.70 \times \log \mathrm{DOC} ; \mathrm{r}^{2}=0.77 ; \mathrm{p}<0.001, \mathrm{n}=17$ (dashed line for autotrophic conditions). (e) $\log \mathrm{BR}=0.72+1.24 \times \log \mathrm{DPP} ; \mathrm{r}^{2}=0.50 ; \mathrm{p}<0.005, \mathrm{n}=15$ (solid line for heterotrophic conditions). 

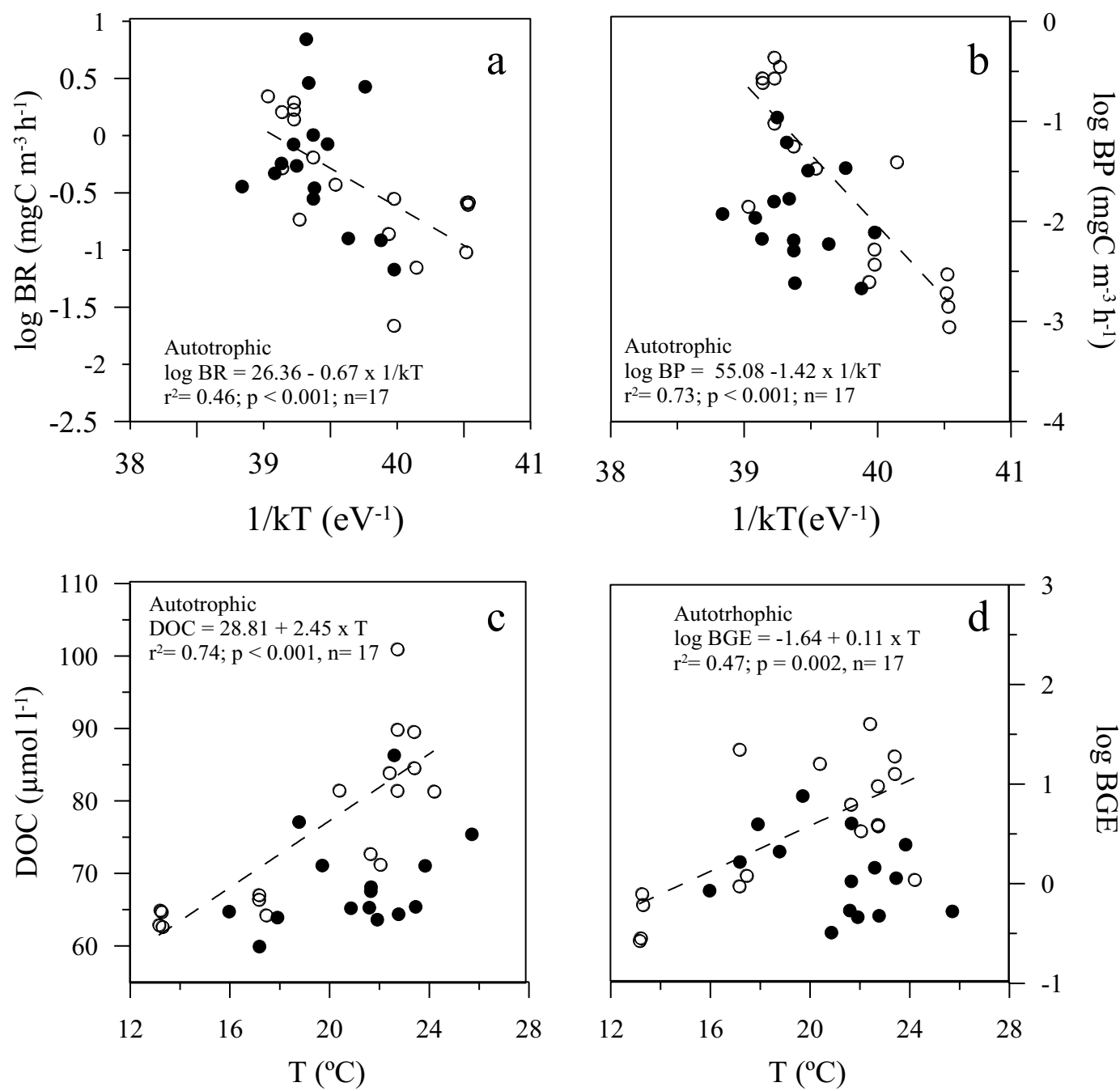

Figure 8. Temperature dependence relationship between log-transformed (a) Bacterial respiration and (b) Bacterial production $v s$ water temperature (1/kT with $\mathrm{k}$, the Boltzmann's constant $\left(8.61773410^{-5} \mathrm{eV} \mathrm{K}^{-1}\right)$ and $\mathrm{T}$ the water temperature $\left({ }^{\circ} \mathrm{K}\right)$ ). (c) Dissolved organic carbon (DOC) and (d) Log-transformed bacterial growth efficiency $v s$ water temperature $\left({ }^{\circ} \mathrm{C}\right)$. Black and white dots represent heterotrophic and autotrophic conditions, respectively. The dashed lines and equations parameters represent the significant fitted model II regressions.

Our results showed a robust relationship between DPP and PPP with photosynthetic proxy biomass (Chl- $a$ ) in autotrophic waters, while they were not correlated in heterotrophic waters. At the Bay of Villefrance-sur-Mer, maximum rates of DPP and PPP were registered during March when nitrate and chlorophyll- $a$ concentrations were higher and seawater temperature was lower. This situation corresponds with the spring phytoplankton bloom and is followed by an increase in bacterial production as a consequence of increased DPP ${ }^{19,47}$. However, the lack of correlation between DPP and PPP with chlorophyll- $a$ under heterotrophic conditions, may be attributable to a strong nutrient limitation for phytoplankton growth ${ }^{48}$, due to process such as grazing ${ }^{16}$ or to phytoplankton lysis $^{49}$. Despite the general low nutrient concentrations measured, during the spring bloom of March, the high nitrate concentrations measured $\left(>1\right.$ up to $4 \mu \mathrm{mol} \mathrm{l}^{-1}$ ) were similar to those registered in the same area ${ }^{2}$, but lower than other oligotrophic Mediterranean regions (up to $7.0 \mu \mathrm{mol} \mathrm{l}{ }^{-1}$ for nitrate in ${ }^{14}$ ).

Contrary to the previous described situation ${ }^{2,14,50}$, during summer at the Bay of Palma, the lowest nitrate concentration co-occurred with elevated water temperature $\left(23.4^{\circ} \mathrm{C}\right)$ and high DOC concentrations $\left(90 \mu \mathrm{mol} \mathrm{l}^{-1}\right)$. Some authors ${ }^{9,51}$ reported an accumulation of DOC during summer and autumn and attributed this to the inability or inefficiency of bacteria to use it under nutrient limitations, the so-called malfunctioning microbial loop ${ }^{52}$.

However, not only DOC, but also phytoplankton DPP has been considered an important carbon source to support bacterial metabolism ${ }^{18,19}$. In our study, we observed a positive correlation between DPP and BR, but exclusively when the system was heterotrophic. Under heterotrophic nutrient-deplete conditions, the fresh and labile carbon from phytoplankton production (DPP) may be firstly respired for bacterial basal metabolism ${ }^{53}$. Although, under the same heterotrophic scenario, bacterial production is correlated to DOC concentrations instead of DPP, probably due to the extra resources needed for bacterial growth or production, than those used to maintain basal bacterial respiration ${ }^{31}$. Therefore, at resource limiting conditions when phytoplankton production was too low 
to sustain BP, labile DOC from nearby seagrass meadows may be used as an organic carbon source ${ }^{54-56}$. Since abundant beds of Posidonia oceanica were present in both bays, a large fraction of the DOC used for bacterial production may come from the exported carbon from benthic organisms ${ }^{56,57}$.

On the other hand, under autotrophic conditions, bacterial metabolism, was positively correlated with DOC concentrations and DPP was potentially sufficient to sustain the bacterial carbon demand (DPP/BCD $>1$ ). These results suggest that DPP contributed signifiicantly to the labile DOC pool under autotrophic conditions and bacteria were growing actively when DOC stock concentration was higher enough to maintain bacterial metabo$\operatorname{lism}^{2,9,28,58,59}$. The highest DPP/BCD ratio was found in Villefranche's Bay during March when the spring bloom occurred and picoeukaryotes biomass was higher than other picoautotrophs groups. Although picoeukaryotes only accounted $3 \%$ of the total autotrophic biomass, concurred with the higher DPP concentrations measured ${ }^{60,61}$ during that period.

The previous reported BGE values depend, however, on the particular leucine-to-carbon conversion factor used $^{31}$. In this work, bacterial production was estimated from in situ incubations and calculated with empirically determined leu-to- $\mathrm{C}$ conversion factors as emphasized in recent studies ${ }^{27,62,63}$. Bacterial production values $(0.001$ to $0.44 \mathrm{mg} \mathrm{C} \mathrm{m}^{-3} \mathrm{~h}^{-1}$ ) were within the range reported in other Mediterranean coastal sites ${ }^{14,36,64}$, being more active during autotrophic periods, and leading to higher BGE values up to 4 -fold compare to those periods where heterotrophic conditions dominated.

It has also been described that bacterial respiration contribute with a significant amount to total community respiration, frequently more than $50 \%^{7,25,65}$. In our study, bacterial respiration represented, on average, $62 \%$ of the total community respiration and did not depend on the metabolic balance of the system. However, bacterial respiration mean value at both coastal oligotrophic environments $\left(1.9 \pm 0.2 \mathrm{mmol} \mathrm{C} \mathrm{m}^{-3} \mathrm{~d}^{-1}\right)$ was substantially lower than the average for coastal regions $\left(7.1 \pm 12.2 \mathrm{mmol} \mathrm{C} \mathrm{m}^{-3} \mathrm{~d}^{-1}\right)$ given in the revision of Robinson ${ }^{39}$. Indeed, bacterial respiration was only slightly higher than open ocean value $\left(1.3 \pm 0.2 \mathrm{mmol} \mathrm{C} \mathrm{m}^{-3} \mathrm{~d}^{-1}\right)$, probably showing the general oligotrophic nature of Mediterranean coastal waters.

Our BGE values (0.3-40.6\%) were within the range of published values for the Mediterranean Sea ${ }^{2,14,36,58,66}$. However, the median BGE (1.6\%) was substantially lower than the value given for coastal regions (16\%) and even the open ocean $(8 \%)^{39}$, although it should be noted that this review ${ }^{39}$ did not include any data from the coastal oligotrophic Mediterranean.

Temperature, nutrient concentrations, dissolved organic matter lability and bacterial taxonomic composition have been regarded among the main factors that can influence $\mathrm{BGE}^{14}$. Robinson ${ }^{39}$ suggested that most of the $\mathrm{BGE}$ variability within oligotrophic waters is explained by bacterial respiration. Other authors ${ }^{31}$ found that BGE is not directly regulated by temperature, but by the availability of substrates for growth. According to our results, temperature explains a large part of BGE (47\%), bacterial respiration (46\%) and production variances $(73 \%)$ when there is a not nutrient limitation. Indeed, the metabolic status of the system is a critical factor determining the temperature-dependence of bacterial metabolic rates. Consequently, the significant and positive relationships between temperature and bacterial metabolic rates (bacterial production and respiration, BGE) during periods of net autotrophy did not hold for heterotrophic periods. Our results confirm that substrate availability is a key factor governing the temperature dependence of heterotrophic bacterial metabolism ${ }^{31,67}$. Temperature is a relevant factor under autotrophic conditions, when our system is in the stage between the bottom-up and top-down control $^{68}$. However, temperature is not a main driver of bacterial metabolism under heterotrophic conditions, due to the limited resource availability (bottom-up control).

The lower slope of the bacterial respiration regression $\left(\mathrm{Ea}_{\mathrm{BR}}=0.67 \mathrm{eV}\right)$ indicates a lower activation energy required for this process relative to that of bacterial production $\left(\mathrm{Ea}_{\mathrm{BP}}=1.42 \mathrm{eV}\right)$, what confirms their different temperature-dependence as an intrinsic characteristic of two independent biochemical processes ${ }^{59}$.

The bacterial respiration activation energy value estimated in this study $\left(\mathrm{Ea}_{\mathrm{BR}}=0.67 \mathrm{eV}\right)$ is very close to the theoretical Ea of $0.65 \mathrm{eV}$ predicted by the Metabolic Theory of Ecology for respiratory processes ${ }^{33,34}$. Compared to previous works, our bacterial respiration Ea value is lower than the values reported by Mazuecos ${ }^{69}$ for the dark ocean $(0.90 \mathrm{eV})$ and higher than those values for the global ocean $\left(E a_{\mathrm{BR}}=0.589 \mathrm{eV}^{31}\right),\left(E a_{\mathrm{BR}}=0.57 \mathrm{eV}^{70}\right)$.

Bacterial production activation energy $\left(\mathrm{Ea}_{\mathrm{BP}}=1.42 \mathrm{eV}\right)$ is more than twice the maximum value described by Morán ${ }^{71}$ (from -0.14 to $0.67 \mathrm{eV}$ ), although it is within the range described by Arandia-Gorostidi ${ }^{72}(-0.3$ to $1.46 \mathrm{eV}$ ) both for the NE Atlantic coastal waters, and slightly higher than the in situ bacterial production measured at the Baltic Sea $\left(1.24 \pm 0.16 \mathrm{eV}^{73}\right)$. The relationship of bacterial metabolic rates with temperature under autotrophic conditions, agrees with higher Eas values during the highest nutrient concentration ${ }^{71}$ and productive bloom periods ${ }^{67,72}$.

We conclude that the metabolic status (autotrophic vs heterotrophic) of the oligotrophic coastal Mediterranean studied systems, determines the source of organic carbon where the bacterial communities are supported by, as well as the temperature dependence of microbial metabolic processes.

\section{Material and Methods}

Study site and sampling. The spatial variability was investigated in the Bay of Palma in June 2002 (Fig. 1a). Four stations were sampled: Enderrocat $\left(39.4^{\circ} \mathrm{N} 2.7^{\circ} \mathrm{E}\right)$, Station $4\left(39.5^{\circ} \mathrm{N} 2.4^{\circ} \mathrm{E}\right)$ in the east of the bay and Bahía $\left(39.5^{\circ} \mathrm{N} 2.6^{\circ} \mathrm{E}\right)$ and Posidonia $\left(39.5^{\circ} \mathrm{N} 2.5^{\circ} \mathrm{E}\right)$ located in the west. Stations Posidonia and Bahia are located above Posidonia oceanica meadows and all stations were sampled at four depths (Table 1). Posidonia and Enderrocat are shallower (approximately $10 \mathrm{~m})$ than Bahia and Station $4(30 \mathrm{~m})$. The temporal variability was studied in the oligotrophic coastal Bay of Villefranche in October and November 2002, March and July 2003 at four depths (Table 1). Point B located at the entrance of the bay $\left(43^{\circ} 41^{\prime} \mathrm{N} ; 7^{\circ} 19^{\prime} \mathrm{E}\right.$, Fig. 1b) is a long-term monitoring station. All bottle samples were incubated in situ during $24 \mathrm{~h}$ on a vertical line attached to a floating buoy. 
Hydrography, irradiance and nutrients. Vertical profiles of temperature, salinity and oxygen saturation were obtained at each station using a SeaBird SBE19 CTD in the Bay of Palma or SBE25 in the Bay of Villefranche. Profiles of light penetration were performed with a LI-COR spherical sensor (LI-193SA) connected to a LI-1400 data-logger. Seawater was collected at four depths within the euphotic layer at each station (Table 1) using single 121 Niskin bottles. Dissolved inorganic nutrients concentrations were measured using automated colorimetric techniques after filtration through Whatman GF/F glass fibre filters ${ }^{74}$. Dissolved silicate was measured after filtration through $0.45 \mu \mathrm{m}$ polyvinylidene fluoride membrane filters (PVDF, Millipore). Chlorophyll- $a$ was measured on GF/F filters that were stored frozen until extraction and analysis by high-performance-liquid chromatography ${ }^{75}$.

Dissolved organic carbon (DOC). Due to the low particulate carbon concentrations in the two sites, total organic carbon samples were collected and not filtered in order to minimize the risk of contamination. Samples of DOC concentration were collected in combusted $\left(450^{\circ} \mathrm{C}\right.$ for $24 \mathrm{~h}$ ) glass ampoules (Wheaton), acidified with $85 \%$ $\mathrm{H}_{3} \mathrm{PO}_{4}$ flame-sealed immediately after collection and stored in the dark at ambient temperature pending analysis. DOC concentration was measured by high temperature combustion with a Shimadzu TOC-5000 total organic carbon analyser. All concentrations are reported as the average of three replicate injections.

Picoplankton abundance. The abundances of heterotrophic prokaryotes, Prochlorococcus spp, Synechococcus spp and photosynthetic picoeukaryotes were estimated using a bench-top flow cytometer (Becton and Dickinson FACScalibur) equipped with a laser emitting at $488 \mathrm{~nm}$. Aliquots of $2 \mathrm{ml}$ were fixed with $1 \%$ paraformaldehyde and $0.05 \%$ of glutaraldehyde (final concentration), frozen in liquid $\mathrm{N}_{2}$ and stored at $-80^{\circ} \mathrm{C}$ pending analysis. The samples for heterotrophic prokaryotes abundance were previously stained with Syto-13 Molecular Probes $(2.5 \mu \mathrm{M})$ and an aliquot of $0.96 \mu \mathrm{m}$ fluorescent latex beads (Polysciences) was also added as internal standard to each tube. The beads were calibrated every day using a beads solution (TrueCount beads) for which the bead abundance is precisely known. Heterotrophic prokaryotes abundance was identified in plots of side scatter (SSC) versus green fluorescence (FL1) as described by ${ }^{76}$. Prochlorococcus spp and Synechococcus spp were identified in plots of SSC versus orange fluorescence (FL2) and red fluorescence (FL3). PA had a higher SSC and FL3 than both Prochlorococcus spp and Synechococcus spp and no FL2 signal. In order to convert cell abundance to carbon biomass it was used, the conversion factors proposed by ${ }^{77}: 12 \mathrm{fg} \mathrm{C}^{-1 l^{-1}}$ for heterotrophic prokaryotes, $1500 \mathrm{fg} \mathrm{C}$ cell $^{-1}$ for picoeukaryotes, $32 \mathrm{fg} \mathrm{C}$ cell $^{-1}$ for Prochlorococcus spp, and $100 \mathrm{fg} \mathrm{C} \mathrm{cell}^{-1}$ for Synechococcus spp. The total phytoplankton carbon biomass was estimated using a carbon-to-chlorophyll- $a$ ratio of $120^{78}$.

Primary production ${ }^{14} \mathrm{C}$ technique. The incorporation of carbon into the dissolved and particulate fractions was measured using the ${ }^{14} \mathrm{C}$ technique ${ }^{79}$. Water samples $(30 \mathrm{ml})$ were transferred to one dark and three light bottles and incubated in situ at each depth and station. The samples were incubated in situ on a vertical line from sunrise to sunset after addition of $30 \mu \mathrm{Ci}(1110 \mathrm{Kbq})$ of sodium bicarbonate $\left(\mathrm{NaH}^{14} \mathrm{CO}_{3}\right)$. Upon completion of the incubation, two $5 \mathrm{ml}$ aliquots of each sample were placed into $20 \mathrm{ml}$ scintillation vials for determination of total labelled organic carbon (Total Primary Production $=$ DPP + PPP). The unit for DPP and PPP were estimated by the incubation time, which was the daylight time $\left(\mathrm{mg} \mathrm{m}^{-3} \mathrm{~h}^{-1}\right)$. Two more $5 \mathrm{ml}$ aliquots of each sample were filtered through $0.22-\mu \mathrm{m}$ mixed cellulose esters membrane filters (Millipore) for determination of PPP and the filtrate was collected for determination of DPP. Filters were placed into vials and exposed to concentrated hydrochloric acid fumes for a minimum of $12 \mathrm{~h}$ before the addition of $3.5 \mathrm{ml}$ Packard Ultima Gold (PerkinElmer) liquid scintillation cocktail. Liquid samples (total primary production and DPP) were acidified with $100 \mu$ of hydrochloric acid $(5 \mathrm{~N})$ and bubbled with air for $2 \mathrm{~h}$ before addition of $15 \mathrm{ml}$ Ultima Gold XR (PerkinElmer) liquid scintillation cocktail. Radioactivity (dpm) was measured in a Packard Tri-Carb 4000 scintillation counter. Counts from the dark bottles were subtracted from counts measured in the light bottles to correct for non-photosynthetic ${ }^{14} \mathrm{C}$-incorporation. The radioactivity of the $\mathrm{NaH}^{14} \mathrm{CO}_{3}$ added to each sample was estimated from $20 \mu \mathrm{l}$ aliquots.

Bacterial metabolism. To estimate in situ community respiration, the first set of seawater samples were incubated in dark BOD (Biological Oxygen Demand) bottles $(60 \mathrm{ml})$ on a vertical line in situ during $24 \mathrm{~h}$. At each station and depth, 5 bottles were immediately fixed with Winkler reagents ${ }^{80}$ (time 0 ) and five more bottles were fixed after $24 \mathrm{~h}$. The second set of samples was incubated under dark condition in a temperature-controlled incubator simulating in situ temperature to calculate incubator community respiration. The third set of samples was filtered ( $142 \mathrm{~mm}$ diameter, $0.8 \mu \mathrm{m})$ to include just the bacterial fraction to estimate the incubator bacterial respiration. The filtration was carried out with a low vacuum pressure system at each station and depth. No more than 101 of a given sample was filtered through the same filter. The percentage of oxygen consumption in filtered seawater samples compared to incubator whole seawater samples, enabled us to estimate incubator bacterial respiration. This percentage was applied to the in situ community respiration to calculate the in situ bacterial respiration.

To estimate the effect of filtration on bacterial metabolism, bacterial abundance and production, and DOC concentration were compared at each station and bay between filtered and unfiltered samples at each depth.

To estimate the effect of incubation time on bacterial metabolism, at each station of the Bay of Palma (S4, Posidonia, Enderrocat and Bahia) and depth (surface and bottom) an extra set of filtered and unfiltered seawater samples were incubated in dark BOD bottles $(60 \mathrm{ml})$ during 12, 24 and 48 hours to estimate community and bacterial respiration. For bacterial production rates, seawater samples were incubated in borosilicate bottles on a vertical line in situ. At each depth and station, three replicates were recovered at sunrise ( $0 \mathrm{~h}$ of incubation), midday ( $6 \mathrm{~h}$ of incubation) and sunset (about $12 \mathrm{~h}$ of incubation depending on the season). 
Dissolved oxygen concentration was determined by titration with a potentiometric end-point detection ${ }^{80}$. Analyses to estimate respiration were performed with a redox electrode (9778-SC, Orion) and a custom built titrator. Bacterial production was estimated as the rate of ${ }^{3} \mathrm{H}$-leucine incorporation using standard methods ${ }^{81}$ in Eppendorf vials. Sea water samples were transferred to Eppendorf vials $(1.5 \mathrm{ml})$. Three were spiked with $5 \mu \mathrm{l}$ of cold leucine ( $20 \mathrm{nM}$ final concentration) and $25 \mu$ of ${ }^{3} \mathrm{H}$-leucine ( $10 \mathrm{nM}$ final concentration; Amersham, specific activity $170 \mu \mathrm{Ci} \mathrm{nmol}^{-1}$ ). The fourth sample, to which $100 \mu \mathrm{l}$ of $100 \%$ trichloroacetic acid was immediately added, served as a control.

The conversion factor required to express the incorporation of leucine into carbon units was estimated at stations Station 4 and Enderrocat at the surface $(0.5 \mathrm{~m})$ and bottom depth ( 33 and $16 \mathrm{~m}$, respectively) following the procedure proposed $\mathrm{in}^{82}$. A sample $(1.8 \mathrm{~L})$ was filtered through a $0.2 \mu \mathrm{m}$ polycarbonate membrane previously rinsed with milliQ water and with sample water and placed in a bottle with 0.21 of unfiltered water. The incubation lasted for $2 \mathrm{~d}$ in a temperature-controlled incubator simulating in situ temperature. Aliquots for bacterial production (leucine incorporation) and abundance (cytometry) were processed every $6 \mathrm{~h}$. The conversion factor (CF) was calculated using the relationship derived by Kirchman and Ducklow in ${ }^{82}$ :

$$
C F=\mu \frac{e^{B}}{e^{b}}
$$

Where $\mu$ is the growth rate $\left(\mathrm{d}^{-1}\right)$ determined from the change in biomass over time, $\mathrm{e}^{\mathrm{B}}$ is the $\mathrm{y}$-intercept of $\mathrm{Ln}$ (biomass in cell ml $\mathrm{m}^{-1}$ ) $v$ s time and $\mathrm{e}^{\mathrm{b}}$ is the y-intercept of $\mathrm{Ln}$ (leucine incorporation in $\mathrm{pmol} \mathrm{Leu}^{-1} \mathrm{l}^{-1} \mathrm{~h}^{-1}$ ) $v s$ time. Four values of conversion factors were obtained and the average $\left(1.15 \pm 0.33 \mathrm{~kg} \mathrm{C} \mathrm{mol}^{-1}\right.$; see Table 1 Supplementary Information) was used to convert leucine incorporation to carbon uptake for bacterial carbon demand and growth efficiency (BGE) calculations. BGE was estimated as the ratio of bacterial production to total bacterial carbon demand (BP $+B R)$. A respiratory quotient (RQ) of 1 was assumed ${ }^{24}$.

Net community production (NCP). For estimating production of dissolved oxygen, seawater samples (10 replicates) were transferred into transparent BOD bottles $(60 \mathrm{ml})$ and incubated on a vertical line in situ during $24 \mathrm{~h}$. At each station and depth, incubations started at sunrise. Five bottles were immediately fixed with Winkler reagents $^{80}$ (time 0 ) and 5 other bottles were fixed at the following sunrise ( $24 \mathrm{~h}$ incubation). The dissolved oxygen concentration was determined as explained above. NCP was estimated by regressing $\mathrm{O}_{2}$ against time.

Statistical analysis. One-way analysis of variance ANOVA (Statistica 5.0) was performed to evaluate differences among trophic status systems. Variance homogeneity was tested with Cochran's analysis. The Student-Newman-Keuls test (SNK) was used to discriminate among different treatments after a significant F-test. A Mann-Whitney U test was used when the data were not strictly parametric. The regression model type II was used to evaluate the relationship between variables when both variables were subject to measurement error.

Received: 21 June 2019; Accepted: 28 October 2019;

Published online: 27 November 2019

\section{References}

1. González, N., Gattuso, J. \& Middelburg, J. Oxygen production and carbon fixation in oligotrophic coastal bays and the relationship with gross and net primary production. Aquat. Microb. Ecol. 52, 119-130 (2008).

2. Bonilla-Findji, O., Gattuso, J.-P., Pizay, M.-D. \& Weinbauer, M. G. Autotrophic and heterotrophic metabolism of microbial planktonic communities in an oligotrophic coastal marine ecosystem: seasonal dynamics and episodic events. Biogeosciences 7 , 3491-3503 (2010).

3. Regaudie-de-Gioux, A. \& Duarte, C. M. Global patterns in oceanic planktonic metabolism. Limnol. Oceanogr. 58, 977-986 (2013).

4. Gattuso, J.-P., Frankignoulle, M. \& Wollast, R. Carbon and carbonate metabolism in coastal aquatic ecosystems. Annu. Rev. Ecol. Syst. 29, 405-434 (1998).

5. Ducklow, H. Microbial services: challenges for microbial ecologists in a changing world. Aquat. Microb. Ecol. 53, 13-19 (2008).

6. del Giorgio, P. A., Cole, J. J. \& Cimbleris, A. Respiration rates in bacteria exceed phytoplankton production in unproductive aquatic systems. Nature 385, 148-151 (1997).

7. del Giorgio, P. A. \& Duarte, C. M. Respiration in the open ocean. Nature 420, 379-384 (2002).

8. Azam, F. \& Malfatti, F. Microbial structuring of marine ecosystems. Nat. Rev. Microbiol. 5, 782-791 (2007).

9. Santinelli, C., Sempéré, R., Wambeke, F. V., Charriere, B. \& Seritti, A. Organic carbon dynamics in the Mediterranean Sea: An integrated study. Glob. Biogeochem. Cycles 26 (2012).

10. Navarro, N., Agustí, S. \& Duarte, C. M. \& others. Plankton metabolism and dissolved organic carbon use in the Bay of Palma, NW Mediterranean Sea. Aquat. Microb. Ecol. 37, 47-54 (2004).

11. Gazeau, F. et al. Whole-system metabolism and $\mathrm{CO}_{2}$ fluxes in a Mediterranean Bay dominated by seagrass beds (Palma Bay, NW Mediterranean). Biogeosciences 2, 43-60 (2005).

12. Myklestad, S. M. Dissolved organic carbon from phytoplankton. in Marine Chemistry (ed. Wangersky, P. J.) 111-148 (Springer Berlin Heidelberg, 2000), https://doi.org/10.1007/10683826 5.

13. Nagata, T. Production mechanisms of dissolved organic matter. in Microbial ecology of the oceans 121-152 (Wiley-Liss, 2000).

14. Alonso-Sáez, L. et al. Factors controlling the year-round variability in carbon flux through bacteria in a coastal marine system. Ecosystems 11, 397-409 (2008).

15. López-Sandoval, D. C. \& Fernández, A. \& Marañón, E. Dissolved and particulate primary production along a longitudinal gradient in the Mediterranean Sea. Biogeosciences 8, 815-825 (2011).

16. Teira, E., Pazó, M. J., Serret, P. \& Fernández, E. Dissolved organic carbon production by microbial populations in the Atlantic Ocean. Limnol. Oceanogr. 46, 1370-1377 (2001).

17. Cole, J. J., Likens, G. E. \& Strayer, D. L. Photosynthetically produced dissolved organic carbon: An important carbon source for planktonic bacteria 1. Limnol. Oceanogr. 27, 1080-1090 (1982)

18. Morán, X. A. G., Estrada, M., Gasol, J. M. \& Pedrós-Alió, C. Dissolved primary production and the strength of phytoplanktonbacterioplankton coupling in contrasting marine regions. Microb. Ecol. 44, 217-223 (2002).

19. Baines, S. B. \& Pace, M. L. The production of dissolved organic matter by phytoplankton and its importance to bacteria: Patterns across marine and freshwater systems. Limnol. Oceanogr. 36, 1078-1090 (1991). 
20. Morán, X. A. G. \& Alonso-Sáez, L. Independence of bacteria on phytoplankton? Insufficient support for Fouilland \& Mostajir’s (2010) suggested new concept: Bacterioplankton independence on phytoplankton? FEMS Microbiol. Ecol. 78, 203-205 (2011).

21. Fouilland, E. \& Mostajir, B. Revisited phytoplanktonic carbon dependency of heterotrophic bacteria in freshwaters, transitional, coastal and oceanic waters. FEMS Microbiol. Ecol. 73, 419-429 (2010).

22. Gasol, J. M., Vázquez-Domínguez, E., Vaqué, D., Agustí, S. \& Duarte, C. M. Bacterial activity and diffusive nutrient supply in the oligotrophic Central Atlantic Ocean. Aquat. Microb. Ecol. 56, 1-12 (2009).

23. del Giorgio, P. A. \& Cole, J. J. Bacterial energetics and growth efficiency. in Microbial ecology of the oceans 289-325 (John Wiley \& Sons, 2000).

24. del Giorgio, P. A. \& Cole, J. J. Bacterial growth efficiency in natural aquatic systems. Annu. Rev. Ecol. Syst. 29, 503-541 (1998).

25. Rivkin, R. B. \& Legendre, L. Biogenic carbon cycling in the upper ocean: effects of microbial respiration. Science 291, 2398-2400 (2001).

26. Alonso-Sáez, L. et al. Seasonality in bacterial diversity in north-west Mediterranean coastal waters: assessment through clone libraries, fingerprinting and FISH. FEMS Microbiol. Ecol. 60, 98-112 (2007).

27. del Giorgio, P. Adel et al. Coherent patterns in bacterial growth, growth efficiency, and leucine metabolism along a northeastern Pacific inshore-offshore transect. Limnol. Oceanogr. 56, 1-16 (2011).

28. Lee, C. W., Bong, C. W. \& Hii, Y. S. Temporal variation of bacterial respiration and growth efficiency in tropical coastal waters. Appl Env. Microbiol 75, 7594-7601 (2009).

29. Gasol, J. M. et al. Towards a better understanding of microbial carbon flux in the sea. Aquat. Microb. Ecol. 53, 21-38 (2008).

30. Jahnke, R. A. \& Craven, D. B. Quantifying the role of heterotrophic bacteria in the carbon cycle: A need for respiration rate measurements. Limnol. Oceanogr. 40, 436-441 (1995).

31. López-Urrutia, Á. \& Morán, X. A. G. Resource limitation of bacterial production distorts the temperature dependence of oceanic carbon cycling. Ecology 88, 817-822 (2007).

32. Rochelle-Newall, E. J., Torréton, J.-P., Mari, X. \& Pringault, O. Phytoplankton-bacterioplankton coupling in a subtropical South Pacific coral reef lagoon. Aquat. Microb. Ecol. 50, 221-229 (2008).

33. Gillooly, J. F., Brown, J. H., West, G. B., Savage, V. M. \& Charnov, E. L. Effects of rize and temperature on metabolic rate. Science 293, $2248-2251$ (2001).

34. Brown, J. H., Gillooly, J. F., Allen, A. P., Savage, V. M. \& West, G. B. Toward a metabolic theory of ecology. Ecology 85, 1771-1789 (2004).

35. Allen, A. P., Gillooly, J. F. \& Brown, J. H. Linking the global carbon cycle to individual metabolism. Funct. Ecol. 19, 202-213 (2005).

36. Céa, B. et al. An annual survey of bacterial production, respiration and ectoenzyme activity in coastal NW Mediterranean waters: temperature and resource controls. Environ. Sci. Pollut. Res. 22, 13654-13668 (2015).

37. García-Corral, L. S., Martinez-Ayala, J., Duarte, C. M. \& Agusti, S. Experimental assessment of cumulative temperature and UV-B radiation effects on Mediterranean plankton metabolism. Front. Mar. Sci. 2, 48 (2015).

38. Gattuso, J.-P., Peduzzi, S., Pizay, M.-D. \& Tonolla, M. Changes in freshwater bacterial community composition during measurements of microbial and community respiration. J. Plankton Res. 24, 1197-1206 (2002).

39. Robinson, C. Heterotrophic bacterial respiration. in Microbial Ecology of the Oceans 299-334 (John Wiley \& Sons, Ltd, 2008),

40. Carlson, C. A. \& Ducklow, H. W. Growth of bacterioplankton and consumption of dissolved organic carbon in the Sargasso Sea. Aquat. Microb. Ecol. 10, 69-85 (1996).

41. Gasol, J. A framework for the assessment of top-down vs. bottom-up control of heterotrophic nanoflagellate abundance. Mar. Ecol. Prog. Ser. 113, 291-300 (1994).

42. Calvo-Diaz, A. et al. Decrease in the autotrophic-to-heterotrophic biomass ratio of picoplankton in oligotrophic marine waters due to bottle enclosure. Appl. Environ. Microbiol. 77, 5739-5746 (2011).

43. Wambeke, F., Christaki, U., Giannakourou, A., Moutin, T. \& Souvemerzoglou, K. Longitudinal and vertical trends of bacterial limitation by phosphorus and carbon in the Mediterranean Sea. Microb. Ecol. 43, 119-133 (2002).

44. Eissler, Y. \& Quiñones, R. A. The effect of viral concentrate addition on the respiration rate of Chaetoceros gracilis cultures and microplankton from a shallow bay (Coliumo, Chile). J. Plankton Res. 25, 927-938 (2003).

45. Massana, R., Pedrós-Alió, C., Casamayor, E. O. \& Gasol, J. M. Changes in marine bacterioplankton phylogenetic composition during incubations designed to measure biogeochemically significant parameters. Limnol. Oceanogr. 46, 1181-1188 (2001).

46. Neogi, S. B. et al. Biogeochemical controls on the bacterial populations in the eastern Atlantic Ocean. Biogeosciences 8, 3747-3759 (2011).

47. Serret, P., Fernández, E., Sostres, J. \& Anadón, R. Seasonal compensation of microbial production and respiration in a temperate sea. Mar. Ecol. Prog. Ser. 187, 43-57 (1999).

48. Goldman, J. C., McCarthy, J. J. \& Peavey, D. G. Growth rate influence on the chemical composition of phytoplankton in oceanic waters. Nature 279, 210 (1979).

49. Agustí, S. \& Duarte, C. M. Strong seasonality in phytoplankton cell lysis in the NW Mediterranean littoral. Limnol. Oceanogr. 45, 940-947 (2000).

50. Copin-Montégut, G. \& Avril, B. Vertical distribution and temporal variation of dissolved organic carbon in the North-Western Mediterranean Sea. Deep Sea Res. Part Oceanogr. Res. Pap. 40, 1963-1972 (1993).

51. Céline, F. et al. The accumulation and release of polysaccharides by planktonic cells and the subsequent bacterial response during a controlled experiment. FEMS Microbiol. Ecol. 29, 351-363 (1999).

52. Thingstad, T. F., HagstrÖm, Å. \& Rassoulzadegan, F. Accumulation of degradable DOC in surface waters: Is it caused by a malfunctioning microbial loop? Limnol. Oceanogr. 42, 398-404 (1997).

53. Carvalho, M. C., Schulz, K. G. \& Eyre, B. D. Respiration of new and old carbon in the surface ocean: Implications for estimates of global oceanic gross primary productivity. Glob. Biogeochem. Cycles 31, 975-984 (2017).

54. Eyre, B. D. \& Ferguson, A. J. P. Comparison of carbon production and decomposition, benthic nutrient fluxes and denitrification in seagrass, phytoplankton, benthic microalgae- and macroalgae-dominated warm-temperate Australian lagoons. Mar. Ecol. Prog. Ser. 229, 43-59 (2002).

55. Barron, C., Apostolaki, E. T. \& Duarte, C. M. Dissolved organic carbon fluxes by seagrass meadows and macroalgal beds. Front. Mar. Sci. 1 (2014).

56. Barrón, C. \& Duarte, C. M. Dissolved organic matter release in a Posidonia oceanica meadow. Mar. Ecol. Prog. Ser. 374, 75-84 (2009).

57. Duarte, C. M., Regaudie-de-Gioux, A., Arrieta, J. M., Delgado-Huertas, A. \& Agustí, S. The oligotrophic ocean is heterotrophic. Annu. Rev. Mar. Sci. 5, 551-569 (2013).

58. Lemée, R. et al. Seasonal variation of bacterial production, respiration and growth efficiency in the open NW Mediterranean Sea. Aquat. Microb. Ecol. 29, 227-237 (2002).

59. Apple, J. K., del Giorgio, P. A. \& Kemp, W. M. Temperature regulation of bacterial production, respiration, and growth efficiency in a temperate salt-marsh estuary. Aquat. Microb. Ecol. 43, 243-254 (2006).

60. Buitenhuis, E. T. et al. Picophytoplankton biomass distribution in the global ocean. Earth Syst. Sci. Data 4, 37-46 (2012).

61. Navarro, G., Alvain, S., Vantrepotte, V. \& Huertas, I. E. Identification of dominant phytoplankton functional types in the Mediterranean Sea based on a regionalized remote sensing approach. Remote Sens. Environ. 152, 557-575 (2014).

62. Calvo-Díaz, A. \& Morán, X. A. G. Empirical leucine-to-carbon conversion factors for estimating heterotrophic bacterial production: Seasonality and predictability in a temperate coastal ecosystem. Appl Env. Microbiol 75, 3216-3221 (2009).

63. Teira, E. et al. Local differences in phytoplankton-bacterioplankton coupling in the coastal upwelling off Galicia (NW Spain). Mar. Ecol. Prog. Ser. 528, 53-69 (2015). 
64. Trabelsi, A. \& Rassoulzadegan, F. Effect of bacterial community dynamics on DOC seasonal changes in the north-western Mediterranean Sea. J. Plankton Res. 33, 1249-1262 (2011).

65. Robinson, C. \& Williams, P. le B. Respiration and its measurement in surface marine waters. in Respiration in aquatic ecosystems 147-180 (Oxford University Press, 2005).

66. Kritzberg, E., Arrieta, J. \& Duarte, C. Temperature and phosphorus regulating carbon flux through bacteria in a coastal marine system. Aquat. Microb. Ecol. 58, 141-151 (2010).

67. Huete-Stauffer, T. M., Arandia-Gorostidi, N., Díaz-Pérez, L. \& Morán, X. A. G. Temperature dependences of growth rates and carrying capacities of marine bacteria depart from metabolic theoretical predictions. FEMS Microbiol. Ecol. 91, fiv111 (2015).

68. Morán, X. A. G. et al. Temperature regulation of marine heterotrophic prokaryotes increases latitudinally as a breach between bottom-up and top-down controls. Glob. Change Biol. 23, 3956-3964 (2017).

69. Mazuecos, I. P. et al. Temperature control of microbial respiration and growth efficiency in the mesopelagic zone of the South Atlantic and Indian Oceans. Deep Sea Res. Part Oceanogr. Res. Pap. 95, 131-138 (2015).

70. Yvon-Durocher, G. \& Allen, A. P. Linking community size structure and ecosystem functioning using metabolic theory. Philos. Trans. R. Soc. Lond. B Biol. Sci. 367, 2998-3007 (2012).

71. Morán, X. A. G., Calvo-Díaz, A., Arandia-Gorostidi, N. \& Huete-Stauffer, T. M. Temperature sensitivities of microbial plankton net growth rates are seasonally coherent and linked to nutrient availability. Environ. Microbiol. 20, 3798-3810 (2018)

72. Arandia-Gorostidi, N., Huete-Stauffer, T. M., Alonso-Sáez, L. \& Morán, X. A. G. Testing the metabolic theory of ecology with marine bacteria: different temperature sensitivity of major phylogenetic groups during the spring phytoplankton bloom. Environ. Microbiol. 19, 4493-4505 (2017).

73. Vaquer-Sunyer, R. et al. Dissolved organic nitrogen inputs from wastewater treatment plant effluents increase responses of planktonic metabolic rates to warming. Environ. Sci. Technol. 49, 11411-11420 (2015)

74. Veuger, B. et al. Microbial uptake of dissolved organic and inorganic nitrogen in Randers Fjord. Estuar. Coast. Shelf Sci. 61, 507-515 (2004).

75. Barranguet, C. The role of microphytobenthic primary production in a Mediterranean mussel culture area. Estuar. Coast. Shelf Sci. 44, 753-765 (1997)

76. Gasol, J. M. \& del Giorgio, P. A. Using flow cytometry for counting natural planktonic bacyeria and understanding the structure of planktonic bacterial communities. Sci. Mar. 64, 197-224 (2000).

77. Zubkov, M. V., Sleigh, M. A. \& Burkill, P. H. Assaying picoplankton distribution by flow cytometry of underway samples collected along a meridional transect across the Atlantic Ocean. Aquat. Microb. Ecol. 21, 13-20 (2000).

78. Marañón, E., Cermeño, P. \& Pérez, V. Continuity in the photosynthetic production of dissolved organic carbon from eutrophic to oligotrophic waters. Mar. Ecol. Prog. Ser. 299, 7-17 (2005).

79. Nielsen Steeman, E. The use of radio-active carbon (14C) for measuring organic production in the sea. J Cons Perm Int Explor Mer 18, 117-140 (1952)

80. Carpenter, J. H. The accuracy of the Winkler method for dissolved oxygen analysis. Limnol. Oceanogr. 10, 135-140 (1965).

81. Smith, D. C. \& Azam, F. A simple, economical method for measuring bacterial protein synthesis rates in seawater using $3 \mathrm{H}$-leucine. Mar Microb Food Webs 6, 107-114 (1992).

82. Kemp, P. F., Cole, J. J., Sherr, B. F. \& Sherr, E. B. Handbook of methods in aquatic microbial ecology. (CRC Press, 1993).

\section{Acknowledgements}

Many individuals contributed to the successful completion of the field work, in particular the skippers and crew of the research boats. The CTD data were provided by C. Heyndrickx and the SOMLIT program. The two sampled regions maps were kindly provided by P. Vandromme and F. Gazeau. This research was supported by the European Union in the framework of the EUROTROPH project (contract \# EVK3-CT-2000-00040) and N. González-Benítez was supported by a Marie Curie individual fellowship (MCFI-2001-01425). Additional support was provided by The Netherlands Organisation for Scientific Research (Dutch-French co-operation on sea research programme). L.S. García-Corral was supported by a Juan de la Cierva fellowship from the Spanish Ministry of Science, Innovation and Universities.

\section{Author contributions}

N.G.-B. conducted the field and lab work, did analysis and led article preparation; L.S.G.-C. contributed to data analysis and writing the article; X.A.G.M., J.M., M.D.P. and J.P.G. provided project support and contributed to editing. All authors reviewed the manuscript.

\section{Competing interests}

The authors declare no competing interests.

\section{Additional information}

Supplementary information is available for this paper at https://doi.org/10.1038/s41598-019-53650-z.

Correspondence and requests for materials should be addressed to N.G.-B.

Reprints and permissions information is available at www.nature.com/reprints.

Publisher's note Springer Nature remains neutral with regard to jurisdictional claims in published maps and institutional affiliations.

(c) (i) Open Access This article is licensed under a Creative Commons Attribution 4.0 International

License, which permits use, sharing, adaptation, distribution and reproduction in any medium or format, as long as you give appropriate credit to the original author(s) and the source, provide a link to the Creative Commons license, and indicate if changes were made. The images or other third party material in this article are included in the article's Creative Commons license, unless indicated otherwise in a credit line to the material. If material is not included in the article's Creative Commons license and your intended use is not permitted by statutory regulation or exceeds the permitted use, you will need to obtain permission directly from the copyright holder. To view a copy of this license, visit http://creativecommons.org/licenses/by/4.0/.

(c) The Author(s) 2019 